\title{
Sugaring the Pill: Emilia Pardo Bazán, John Stuart Mill and the Biblioteca de la Mujer
}

\author{
GARETH WOOD \\ University College London
}

\section{Introduction}

Scholarship on Emilia Pardo Bazán has long acknowledged the pivotal role played by several key texts and historical figures in buttressing her advocacy of greater freedom for women. ${ }^{1}$ Among a number of possible examples, Denise DuPont has shown how the evolving representation in Pardo Bazán's work of George Sand, Madame de Staël, and the great Spanish mystic Santa Teresa de Jesús can be used as a barometer of her attitudes to female authority. ${ }^{2}$ Geraldine Scanlon has argued that early study of P. Benito Jerónimo Feijoo left an indelible mark whose clearest trace was the title Pardo Bazán chose for the single-authored literary journal she founded in 1891: by calling it the Nuevo Teatro Crítico, she was implicitly invoking Feijoo's famous eighteenth-century periodical, the Teatro Critico Universal, and his 'defensa de la igualdad intelectual y moral de las mujeres', along with 'su propósito de divulgar nuevas ideas y desterrar errores comunes'. ${ }^{3}$ A further such example is John Stuart Mill, whose The Subjection of Women (1869) appeared in Spanish translation under the imprint of the Biblioteca de la Mujer (henceforth BDLM) edited by Pardo Bazán from 1892 onwards. ${ }^{4}$ It is this connection that the present article will elucidate.

The mission statement of the BDLM indicated it would be a series 'donde tuviesen cabida cuantas obras pueden servir para completar el conocimiento científico, histórico y filosófico de la mujer en todas las épocas y en todas las literaturas'. ${ }^{5}$ It was to foment awareness of the nascent feminist movement, presided over by the foremost female writer of her day. In commercial terms the BDLM evidently failed, as discussion below will make clear. And yet, it continued to inform Pardo Bazán's work for the rest of her career, with at least one example revealed by Elizabeth Ordóñez when she demonstrated conclusively the dialogue between Mill's

\footnotetext{
${ }^{1}$ For an overview of Pardo Bazán’s feminism, see Maryellen Bieder, 'Emilia Pardo Bazán y la emergencia del discurso feminista', in Breve historia feminista de la literatura española, ed.by Myriam Díaz-Diocaretz and Iris M. Zavala, 6 vols (Barcelona: Anthropos, 1993-2000), V: La literatura escrita por la mujer: desde el siglo XIX hasta la actualidad (1998), 75-110; Geraldine Scanlon, 'Emilia Pardo Bazán (1851-1921)', in Mujeres para la historia. Figuras destacadas del primer feminismo, ed. by Rosa María Capel (Madrid: Abada, 2004), 11948.

2 Denise DuPont, 'Masculinity, Femininity, Solidarity: Emilia Pardo Bazán's Construction of Madame de Staël and George Sand', Comparative Literature Studies, 40:4 (2003), 372-93; Writing Teresa: The Saint from Avila at the fin-de-siglo (Lewisburg: Bucknell University Press, 2012), 91-128.

${ }^{3}$ Scanlon, 'Emilia Pardo Bazán (1851-1921)', 125.

4 See, for example, Adna Rosa Rodríguez, La cuestión feminista en los ensayos de Pardo Bazán (A Coruña: Ediciós do Castro, 1991), 141-45.

5 Taken from an advert for the BDLM featured on the flyleaf of Juan Luis Vives, Instruccion de la mujer cristiana, Biblioteca de la Mujer, 6 (Madrid: Renacimiento, 1892), 303.
} 
tract and the author's 1896 novel, Memorias de un solterón. ${ }^{6}$ Although this latter connection has been established beyond doubt, Pardo Bazán's critics have proved surprisingly reluctant to devote sustained attention either to the BDLM series or to La esclavitud femenina, as Mill's tract became in its Spanish incarnation. This article thus seeks to fill a gap in our understanding of Pardo Bazán's career by examining how she presented Mill's explosive attack on the treatment of women in Western society to a public arena which, on the face of it, could scarcely have appeared less receptive to his liberationist message. It will do so in two main ways. Firstly, it will examine in detail the frame offered by the BDLM series as a whole, the final line-up of which comprised the following volumes:

I: María de Jesús de Ágreda, Vida de la Virgen María (1892)
II: John Stuart Mill, La esclavitud femenina (1892)
III: María de Zayas, Novelas (1892)
IV: Padre Mercier (SJ), Reinar en secreto (La Maintenón) (1892)
V: Gonzalve de Nervo, Historia de Isabel la Católica (1892)
VI: Juan Luis Vives, Instrucción de la mujer cristiana (1892?)
VII: Emilia Pardo Bazán, La revolución y la novela en Rusia (1893)
VIII: Emilia Pardo Bazán, Mi romería (1893)
IX: August Bebel, La mujer ante el socialismo (1893)
X: Emilia Pardo Bazán, La cocina española antigua (1913)
XI: Emilia Pardo Bazán, La cocina española moderna (1913)7

How did Mill's text fit in with the other volumes in the BDLM? Can it be helpfully thought of as establishing a dialogue with them and, if so, how? How did Pardo Bazán use her famous Prologue to encourage potential readers to receive Mill's text with as open a mind as possible? Secondly, discussion will focus on the text itself. Not least among matters to be clarified is the vexed question of who produced the translation. The text's most recent editor, as well as other critics, among whom I must count myself, have hitherto been happy to ascribe authorship to Pardo Bazán, whereas this article will argue that such an attribution no longer stands up to scrutiny. ${ }^{8}$ More importantly, what idiosyncrasies does the Spanish version show in its subtle

\footnotetext{
${ }^{6}$ Elizabeth J. Ordóñez , 'Revising Realism: Pardo Bazán’s Memorias de un solterón in Light of Galdós's Tristana and John Stuart Mill', in In the Feminine Mode: Essays on Hispanic Women Writers, ed. by Noël Valis and Carol Maier (London: Associated University Presses, 1990), 146-63. See also Travis Landry, Subversive Seduction: Darwin, Sexual Selection, and the Spanish Novel (Seattle: University of Washington Press, 2012), 23051.
}

${ }^{7}$ The BDLM volumes were published undated. Their dates must therefore be established with the help of contemporary periodicals. Notices announcing the appearance of the first five volumes came out steadily from February to December 1892 in El Día, La Época, La España Moderna, El Heraldo de Madrid, El Liberal, Nuevo Teatro Crítico, Revista Contemporánea, and La Unión Católica. The publication of volumes IV and V is recorded in early December 1892. Volumes VII, VIII, and IX were likewise announced between January and June 1893 in La España Moderna, El Liberal, and Revista Contemporánea. The only difficulty therefore arises in trying to ascertain which year saw publication of Volume VI, Vives's Instrucción de la mijer cristiana. The only reference to it in 1892 is to be found in a letter Pardo Bazán wrote to El Liberal on $30^{\text {th }}$ October where she refers to the on-going printing of the volume. Volume VI is described in the January-FebruaryMarch edition of the Revista Contemporanea as already forming part of the BDLM. On that basis, it seems most likely that it appeared late in 1892.

${ }^{8}$ The recent edition referred to is: John Stuart Mill, La esclavitud femenina, trans. by Emilia Pardo Bazán [sic], ed. by Assumpta Roura (Madrid: Artemisa Ediciones, 2008). Subsequent references to the Spanish text will refer to this edition using the designation LES. Critics who have claimed the translation as Pardo Bazán's own work include Jo Labanyi, Gender and Modernization in the Spanish Realist Novel (Oxford: Oxford University Press, 2000), 39; Ricardo Virtanen, 'El feminismo de Emilia Pardo Bazán en el Nuevo Teatro Crítico', La Tribuna: Cadernos da Casa Museo Emilia Pardo Bazán, 2 (2004), 283-97 (pp. 295-96); Gareth J. 
emendations of Mill's argument? What do those discreet shifts of emphasis, elisions, and suppressions reveal about the editing process, the aspect over which Pardo Bazán appears to have had the greatest control?

\section{The BDLM As Framing Device}

A wealth of insightful research has appeared in the last two decades on Pardo Bazán's advocacy of women's rights through her short fiction, contributions to La España Moderna, the Nuevo Teatro Critico, and public debate both in person and in print. ${ }^{9}$ That task has received dual impetus from the completion of the project to catalogue her archive at the Real Academia Galega and from the publication of extensive scholarly biographies in 2003 and $2007 .{ }^{10}$ In spite of which, the BDLM remains an underexplored corner of her career. Although it receives honourable mention in the biographies referenced above and in any number of the overviews of her work, more detailed scrutiny of the project is conspicuous by its absence; ${ }^{11}$ not least in view of the extensive attention paid to other aspects of her feminist thought, as the articles cited above attest. ${ }^{12}$ Where more detailed comment is forthcoming, it often focuses on Pardo Bazán's rueful admission of failure, appended to the first of the cookbooks - La cocina española antiguapublished in what had started out as a feminist undertaking:

Tiempo ha fundé esta Biblioteca de la Mujer, aspirando a reunir en ella lo más saliente de lo que en Europa aparecía, sobre cuestión tan de actualidad como el feminismo. Suponía yo que en España pudiera quizás interesar este problema, cuando menos, a una ilustrada minoría. No tardé en darme cuenta de que no era así. La Biblioteca tuvo que interrumpirse en el noveno tomo, a pesar de mis esfuerzos por prestarle variedad, mezclando en ella obras de historia y de devoción. Encariñada, sin embargo, con la idea, siempre esperaba el día en que la Biblioteca continuase; sólo que aleccionada por la práctica, y como en los años transcurridos no se hubiesen presentado sino aislados y epidérmicos indicios de que el problema feminista, que tanto se debate y profundiza en el extranjero, fijase la atención aquí, decidí volver a la senda trillada, y puesto que la opinión sigue relegando a la mujer a las faenas caseras, me propuse enriquecer la Sección de

Wood, Javier Marias's Debt to Translation: Sterne, Browne, Nabokov (Oxford: Oxford University Press, 2012), 4. Cristina Patiño Eirín warns against attributing the translation to Pardo Bazán in her review of Roura's edition. See La Tribuna: Cadernos da Casa Museo Emilia Pardo Bazán, 6 (2008), 503-08.

${ }^{9}$ On her short fiction, see Joyce Tolliver, Cigar Smoke and Violet Water: Gendered Discourse in the Stories of Emilia Pardo Bazán (London: Associated University Presses, 1998); Susan M. McKenna, Crafting the Female Subject: Narrative Innovation in the Short Fiction of Emilia Pardo Bazán (Washingston: Catholic University of America Press, 2009); Susan Walter, From the Outside Looking in: Narrative Frames and Narrative Spaces in the Short Stories of Emilia Pardo Bazán (Newark: Juan de la Cuesta, 2010). On La España Moderna, see Rhian Davies, “La cuestión femenina” and La España Moderna (1889-1914)', Bulletin of Spanish Studies, 89:1 (2012), 61-85. On the Nuevo Teatro Crítico, see Geraldine Scanlon, 'Gender and Journalism: Pardo Bazán's Nuevo Teatro Crítico, in Culture and Gender in Nineteenth-Century Spain, ed. by Lou Charnon-Deutsch and Jo Labanyi (Oxford: Oxford University Press, 1996), 230-49; Rocío Charques Gámez, Los artículos feministas en el Nuevo Teatro Crítico de Emilia Pardo Bazán (Alicante: Universidad de Alicante, 2003). On her advocacy of feminism in this period, see Maryellen Bieder, 'Women, Literature, and Society: The Essays of Emilia Pardo Bazán', in Spanish Women Writers and the Essay, ed. by Kathleen M. Glenn and Mercedes Mazquiarán de Rodríguez (Columbia: University of Missouri Press, 1998), 25-54.

${ }^{10}$ Pilar Faus, Emilia Pardo Bazán: su obra, su vida, su época (A Coruña: Pedro Barrié de la Maza, 2003); Eva Acosta, Emilia Pardo Bazán: la luz en la batalla (Barcelona: Lumen, 2007).

${ }^{11}$ Emilia Pardo Bazán: su obra, su vida, su época, I, 532-35; Acosta, 496-97, 519-20.

${ }^{12}$ Charques Gámez (38-49) is one of few critics to give more substantial treatment to the BDLM. She confines her comments to the prologues Pardo Bazán wrote for the first two volumes. An overview of the BDLM is supplied by Rosa Rodríguez (150-53). 
Economía Doméstica con varias obras que pueden ser útiles, contribuyendo a que la casa esté bien arreglada y regida. ${ }^{13}$

Ironically enough, it is the two cookbooks - La cocina española antigua and La cocina española moderna - that are the sole aspect of the BDLM to have received sustained critical analysis. Three scholars in particular have done valuable work in helping to flesh out their cultural context. Central to María Paz Moreno's arguments is the contention that Pardo Bazán used her cocina antigua to poke fun at the Real Academia which had thrice spurned her application for membership; to argue for the superiority of Spanish culinary traditions over French ones; and to elevate the humble cookbook from its lowly station in the literary pecking order by interlacing her text with erudite references to Calderón, Cervantes, Galdós, and Lope. ${ }^{14}$ Lara Anderson has shown how the cookbooks negotiate anxieties of taste and influence between Spanish national dishes and the dominant French culinary models in bourgeois Europe. ${ }^{15}$ While according to Rebecca Ingram, the cookbooks' proscriptions and recommendations around the issue of good taste speak to anxieties over the construction of the middle-class household against the backdrop of efforts to define the nation state in Restoration Spain. ${ }^{16}$ The present discussion will seek to complement their work by showing that the earlier instalments of the BDLM are every bit as deserving of sustained critical scrutiny. Pardo Bazán's downbeat assessment of her project need no longer be the BDLM's epitaph. Thus the first section of this article will place the project in the context of Pardo Bazán's adoption of more radical feminism after 1890.

If the Prologue to La cocina española antigua was in part an acknowledgement that the rallying cry issued by the BDLM had found no answering echo, historians of Restoration Spain have provided ample evidence for why that should have been the case. After all, the position of women in the Spain of the 1890s remained unremittingly subordinate. As well as being largely excluded from higher education and from most of the professions, they remained politically disenfranchised, subject to the legal tutelage of their parents until their mid-twenties or of their husbands in perpetuity, should they marry. ${ }^{17}$ Often pathologized by contemporary doctors as fragile and inherently unstable, the female body was thought to require constant monitoring; while medical manuals sought to dictate how much or how little time women might devote to the most mundane of daily activities such as reading or praying. ${ }^{18}$ As a number of critics have observed, married women faced the potential contradictions that arose from distinct roles as home-maker, mother, sexual partner, and defender of the family's spiritual welfare. ${ }^{19}$ This latter

13 Emilia Pardo Bazán, 'Prólogo', in La cocina española antigua, Biblioteca de la Mujer, 10 (Madrid: Renacimiento, 1913), 1-8 (pp. 1-2).

14 María Paz Moreno, 'La cocina española antigua de Emilia Pardo Bazán: Dulce venganza e intencionalidad múltiple en un recetario ilustrado', La Tribuna: Cadernos da Casa Museo Emilia Pardo Bazán, 4 (2006), 243-51.

${ }^{15}$ Lara Anderon, Cooking Up the Nation: Spanish Culinary Texts and Culinary Nationalism in the Late Nineteenth and Early Twentieth Century (Woodbridge: Tamesis, 2013), 95-119.

${ }^{16}$ Rebecca Ingram, 'Popular Tradition and Bourgeois Elegance in Emilia Pardo Bazán’s cocina española’, Bulletin of Hispanic Studies, 91:3 (2014), 261-74.

17 Geraldine Scanlon, La polémica feminista en la España contemporánea 1868-1974 (Madrid: Akal, 1986), 32-77, 120-35.

${ }^{18}$ For more detailed information on nineteenth-century Spanish medicine and its approach to women, see La mujer en los discursos del género, ed. by Catherine Jagoe, Alda Blanco, and Cristina Enríquez de Salamanca (Barcelona: Icaria, 1998), 305-437.

${ }^{19}$ See, for example, Catherine Jagoe, Ambiguous Angels: Gender in the Novels of Galdós (Berkeley: University of California Press, 1994), 38-41 and passim; Bridget A. Aldaraca, El ángel del hogar: Galdós and the ideology of domesticity in Spain (Chapel Hill: University of North Carolina, 1991). 
responsibility brought them into the sphere of a Catholic Church that had embarked on an intensely conservative re-evangelization of the country in the wake of the threat to its authority presented by the First Republic: hardly fertile ground on which to sow the seeds of Feminism, it seems fair to conclude. Feminist campaigners in this period and until the outbreak of the Spanish Civil War, among them Concepción Arenal, Carmen de Burgos, Margarita Nelken, and Pardo Bazán herself, were forced to confront the fact that many middle- and upper-class women in particular retreated into deeply conservative outlooks because it was the safest option open to them. When reaching out to her 'ilustrada minoría', Pardo Bazán must have given thought to the challenge of where such readers were to be found. As the quotation above indicates, part of the solution she hit upon was to divide the BDLM into discrete sections - 'biográfica', 'histórica', 'literaria', 'novelesca', 'psicológica', 'religiosa', 'sociológica', and, ultimately, 'economía doméstica'. It cannot be coincidental that the first of these sections to receive its corresponding volume was that devoted to religion. Volume I of the BDLM was the Vida de la Virgen María by Sor María de Ágreda, the famous seventeenth-century mystic and long-term correspondent of Felipe IV. Pardo Bazán's editorial selection gives some indication, we might suggest, as to where she imagined she would find her potential audience. As Raymond Carr reminds us:

The most marked feature of the religious revival was a recatholicization of upper-class society in which the aristocracy took the lead. An evangelical rather than an intellectual process, its characteristic instrument was the devotional or charitable organization. These organizations were supported by the female piety of that 'elegant, sanctimonious swarm' of beatas who people the novels of Galdós, by the 'pompous and useless' aristocratic ladies who ran committees against white slavery or who organized protests, social boycotts, or social sieges of anti-clerical ministers. ${ }^{20}$

Given that such organizations were one of the few ways in which women educated enough to read could socialize and share their ideas, Pardo Bazán needed to ensure they were not scared off at the first hurdle by too-radical an approach.

Herself a lifelong Catholic, she did in fact take the opportunity presented by the Vida de la Virgen Maria, an account of the life of the Virgin Mary revealed to Sor María through mystical prayer, to begin the process of thinking through issues pivotal to the case for women's freedom. Her Prologue to the text draws a contrast between the pious and level-headed Sor María and the monarch with whom she corresponded for more than two decades: 'Nadie que lea el Epistolario de la Venerable y compare el rey sensual y voluble con la austera monja, podrá menos de lamentar que la corona de España, en vez de ceñir las sienes de Felipe IV, no rodease las de la magnánima reclusa'. ${ }^{21}$ That 'rey sensual y voluble' had indeed gone down in history as the ruler who presided so ineffectually over a Spain that was falling away from the wealth and influence enjoyed during its Golden Age. Not only might certain women bear favourable comparison, therefore, with the allegedly great men of their day, Sor María's example also contests another of the shibboleths on which male authority stands: the would-be sinfulness of womankind. Her Prologue delivers a rollcall of the Church Fathers - St. Isidore, St. Augustine, and St. Paul whose works ascribe greater susceptibility to temptation to women. By way of refutation, she quotes a passage from José Jiménez Samaniego's life of Sor María in which he reflects on whether a person's sex could be thought to determine his or her ability to receive the Holy Spirit: 'la hazaña de purificar la mente no la obra el sexo, sino la virtud, y es cierto que en la virtud se puede adelantar la mujer al varón'. The final words of Pardo Bazán's Prologue are a heartfelt call: ‘Dichosa y merecedora de eterna alabanza la mujer que dio ocasión a que se estampasen y

\footnotetext{
20 Raymond Carr, Spain 1808-1975, 2nd edn. (Oxford: Oxford University Press, 1982), 465.

${ }^{21}$ Emilia Pardo Bazán, 'Prólogo', in Sor María de Ágreda, Vida de la Virgen María, Biblioteca de la Mujer, 1 (Madrid: Renacimiento, 1892), 5-21 (p. 19).
} 
propugnasen tales doctrinas!'. ${ }^{22}$ Such an argument would appear germane to the cause of women's rights in any era. And yet, it also has pertinent contextual resonance of which we should remain aware. As Frances Lannon has observed, if the re-evangelization drive on which the Church had embarked at this time had one focus in particular, it was sex:

It often seemed that, however hostile Spanish Catholic tradition was to European rationalism and liberalism, the greatest enemy of all was sex. One aspect of a consistently clerical culture was its idealizing of celibacy. Spanish Catholicism was unremittingly puritanical. Schools, youth organizations, publications, and the confessional all concentrated on the preservation of sexual innocence, and warned girls and boys against 'bad companions', unedifying books and papers, and later the cinema. The human body, and particularly the female body, was dangerous. ${ }^{23}$

Confirmation that Pardo Bazán was well aware of the limitations of contemporary theological discourse comes from her correspondence with Manuel Polo y Peyrolón. Writing in April 1886 in response to what would appear to be a request to review his most recent work, Pardo Bazán praises her correspondent for being a committed Catholic who is nevertheless open to new ideas. She goes on to suggest that contemporary ecclesiastical authorities have cut themselves off from 'cultura reflexiva o inspiración creadora' by their intransigence when faced with innovation. ${ }^{24}$ Thus Sor María's Vida de la Virgen María was a hook with which to lure in readers whose conservative inclinations might have seen them otherwise shy away from a book series the stated aim of which was to promote a radical and potentially subversive cause. But Pardo Bazán also used the opportunity to begin undermining the cornerstones of the misogynistic world-view she wished her readers to confront.

Although it may be one thing to express reservations about the Church's shortcomings in private correspondence, it is quite another to do so in a book available on the open market. In that sense, Pardo Bazán's framing of Sor María addresses one of the tensions inherent in its author and in the society she inhabited: that between innovation and secularizing modernity on one side and an embattled traditionalism on the other. Critics have noted that same negotiation in her response to Darwinian theory and, most clearly of all, French Naturalism, where her essentially faith-based outlook confronts more positivistic challenges to its tenets. ${ }^{25}$ Her willingness to confront those challenges and think through them speaks volumes for her intellectual stature. They are equally visible in the BDLM, where the reservations expressed by Mill and August Bebel on the Christian Church in general - and its Catholic branch in particular - sit alongside Sor María de Ágreda and Pardo Bazán's own Mi romería, her travel account of a pilgrimage to Rome to celebrate the fiftieth anniversary of Pope Leo XIII's accession to the priesthood. Although, as we shall see, the final version of Mill elides or attenuates some of his more strident remarks, much of his criticism survives intact. By inviting her female contemporaries to explore such conflicting world-views, she is implicitly advocating the value of testing one's beliefs and ideas through education: the very thing she would consistently state was Spanish women's most pressing need; and, moreover, the very thing Mill's treatise defends with its systematic dismantling of any suggestion that women's innate capacity for learning differs from men's.

${ }^{22}$ Vida de la Virgen María, 21.

${ }^{23}$ Frances Lannon, Privilege, Persecution, and Prophecy: The Catholic Church in Spain 1875-1975 (Oxford: Clarendon Press, 1987), 49-50.

${ }^{24}$ María Luisa Lanzuela Corrella, 'Cartas inéditas de Emilia Pardo Bazán a Manuel Polo y Peyrolón', Boletin de la Biblioteca Menéndez. Pelayo, 65 (1989), 271-303 (p. 294).

${ }^{25}$ See, for example, José Manuel González Herrán, 'Estudio introductorio', in Emilia Pardo Bazán, La cuestión palpitante, ed. by José Manuel González Herrán (Barcelona: Anthropos/Universidad de Santiado de Compostela, 1989), 7-87. 
Our discussion of Pardo Bazán's advocacy of women's rights began by drawing attention to the historical interlocutors she summoned to her cause - P. Feijoo, Madame de Staël, Santa Teresa. As we have just seen from her framing of Sor María, no small part of her argument rested on the notion that authoritative women (Santa Teresa) and enlightened men (Fr. Fiejoo) had always been at the heart of Spain's cultural life and national success. If Sor María's was the one small voice of calm drowned out by Felipe IV's incompetence at the twilight of the Golden Age, the woman who had done so much to herald its arrival - Isabel la Católica - also took her rightful place in the BDLM thanks to Gonzalve de Nervo's biography. The year 1892 marked the four-hundredth anniversary of Columbus's first voyage, with the country's cultural commentators as ever taking the opportunity to weigh up the legacy of empire through publications and public debates in the Madrid Ateneo. Pardo Bazán's contribution can be seen against that backdrop, her Prologue to the biography of the Catholic monarch pointing up an injustice that feminists have denounced consistently ever since - the tendency to airbrush women out of history:

Los estudios acerca de Colón abundan; en cambio escasean los consagrados a Isabel La Católica, su copartícipe en la obra del Descubrimiento del Nuevo Mundo. Parecióme que era conveniente y hasta indispensable incluir sin tardanza en la Biblioteca de la mujer una completa biografía de la santa Reina. ${ }^{26}$

Likewise, María de Zayas, the country's most celebrated female novelist of the Golden-Age, found her place in the series, with Pardo Bazán using her Prologue to advance the claim that the former need not fear comparison with Cervantes: 'es de advertir que algunas de las novelas cortas de doña María de Zayas puede [sic] sostener sin desdoro la comparación con otras del insigne manco [Cervantes]. ${ }^{27}$ We might also note in passing that the editor took care to present herself as defender of her readers' sensibilities. She observes that her selection from the available novellas has omitted several texts 'por culpa de algunas frases vivas y algunas escenas poco veladas (aunque nunca realmente licenciosas), que pueden encontrarse en sus escritos'. ${ }^{28}$ She does, however, make a point of naming those stories she has chosen to exclude, should any curious reader wish to track them down in an alternative edition. But if the great women of Spain's Golden Age could match the achievements of its greatest men, in the case of Zayas, she did so at the same time that 'abogó por los derechos de su sexo y que se dio cuenta tan clara de la injusticia de la sujeción a que le condenan la sociedad y las leyes'.29

Through her choice of texts and presentation of them, Pardo Bazán is producing a feminist re-inscription of the national past with women restored to their rightful place at the heart of Spain's greatest historical achievements; and does so, moreover, at the climax of a century which had witnessed the definitive squandering of that imperial legacy. Such arguments are not just astutely strategic in a public climate where nostalgia for empire was growing among regenerationist intellectuals, they are also in line with other contemporary defences of modernity. ${ }^{30}$ In a persuasive recent study, Jesús Torrecilla has argued that the generation of

\footnotetext{
${ }^{26}$ Emilia Pardo Bazán,. 'Prólogo', in Gonzalve de Nervo, Historia de Isabel la Católica, Biblioteca de la Mujer, 5 (Madrid: Renacimiento, 1892), 6.

${ }^{27}$ Emilia Pardo Bazán, 'Prólogo', in María de Zayas, Novelas, Biblioteca de la Mujer, 3 (Madrid: Renacimiento, 1892), 5-16 (p. 12).

28 'Prólogo', in María de Zayas, Novelas, 15.

29 'Prólogo', in María de Zayas, Novelas, 15-16.

30 See, for example, Robin Fiddian, 'Under Spanish Eyes: Late Nineteenth-Century Postcolonial Views of Spanish American Literature', Modern Language Review, 97:1 (2002), 83-93.
} 
Realist novelists to which Pardo Bazán belonged, and who found themselves attacked for the immorality of their works, went out of its way to emphasize the affinities between the new fictional mode and Spain's literary heritage, most notably Cervantes. ${ }^{31}$ Pardo Bazán makes precisely that point, in fact, in the letter quoted above to Polo y Peyrolón, where she argues that religion and the Church were once: 'madres fecundísimas de artistas incomparables, y a cuyo amparo, en tiempos menos intolerantes y espantadizos que los que corremos, brotó franca y saturada de humanidad y realismo en todos sus poros nuestra gran literatura patria' ${ }^{32}$

If some of the impetus behind the BDLM came from a desire to harness the past in the service of her cause, further motivation arose from Pardo Bazán's desire to establish networks of solidarity in the present. In fact, it looks very much as if she used a review in the Nuevo Teatro Crítico of the Romancero de don Jaime el Conquistador by Blanca de los Ríos to whet the appetite of her readers. She begins by recalling accusations of 'indiferencia absoluta hacia la ilustración de las demás mujeres' levelled against her by a group of 'señoritas librepensadoras', accusations she, needless to say, rejects:

Lo único que adelantaré á mis lectores, es que no ceso de rezar para que Dios me mande una cosechita de Staëles, Ackermanes, Santas Teresas, marquesas de Chatelet, Safos, una nidada, en fin de eminencias hembras, de cualquier color y hechura, a fin de recrearme con su trato, aprovechar su enseñanza, y batir palmas a cada triunfo que consigan en la crítica, en la lírica, en la santidad o en la ciencia. ${ }^{33}$

In other words, we might helpfully see the creation of the BDLM as an attempt to construct and design the very intellectual community Pardo Bazán so yearned for in her daily life. The snapshots that remain of her correspondence attest to the thirst for knowledge of an intelligent and restless mind which feels itself cut off, by accident of geographical location, from the major currents of contemporary thought. Her letters to Blanca de los Ríos, Gabriella Cunninghame Graham, Francisco Giner de los Ríos, Augusto González de Linares, Marcelino Menéndez y Pelayo, Manuel Polo y Peyrolón, and José Yxart demonstrate eagerness both to communicate the fruits of her researches and to receive guidance on those she is yet to undertake. ${ }^{34}$ It was to Yxart that she wrote in the pivotal year 1890 to express gratitude for the welcome he had given her initial moves towards a more openly feminist position: 'No he podido decir de ellos ni la vigésima parte de lo mucho que tengo cavilado sobre la condición de mi sexo en sociedad y ante la ley; acaso algún día pueda dar salida a una ebullición de ideas que estoy poco a poco depurando, ${ }^{35}$ And for her introduction to Mill, Pardo Bazán had Giner to thank, as her

${ }^{31}$ Jesús Torrecilla, 'Power and Resistance: The Reality of Spanish Realism', Symposium, 67:2 (2013), 98110.

32 'Cartas inéditas de Emilia Pardo Bazán a Manuel Polo y Peyrolón’, 294.

${ }_{33}$ Emilia Pardo Bazán, 'Blanca de los Ríos’, Nuevo Teatro Crítico, 8 (1891), 85-92 (pp. 85-86).

${ }^{34}$ Cartas de buena amistad: Epistolario de Emilia Pardo Båán a Blanca de los Ríos (1893-1919), ed. by Ana María Freire López and Dolores Thion Soriano-Mollá (Madrid/Frankfurt: Iberoamericana/Ververunt, 2016); Maryellen Bieder, 'Emilia Pardo Bazán and Gabriela Cunningham Graham: A Literary and Personal Friendship', 89 (2012), 725-49; José Luis Varela, 'E. Pardo Bazán: Epistolario a Giner de los Ríos', Boletín de la Real Academia de la Historia, 198 (2001), 327-48 \& 439-506; Ermitas Penas, 'Giner de los Ríos en la formación de Emilia Pardo Bazán: a propósito de un epistolario’, La Tribuna: Cadernos da Casa Museo Emilia Pardo Bazán, 2 (2004), 103-29; Pilar Faus, 'Epistolario Emilia Pardo Bazán - Augusto González de Linares (1876-1878)', Boletín de la Biblioteca Menéndez. Pelayo, 60 (1984), 271-313; Marcelino Menéndez y Pelayo, Epistolario, ed. by Manuel Revuelta Sañudo, 23 vols (Madrid: Fundación Universitaria Española, 1982-1991); David Torres, 'Veinte cartas inéditas de Emilia Pardo Bazán a José Yxart', Boletín de la Biblioteca Menéndez Pelayo, 53 (1977), 383-409.

35 'Veinte cartas inéditas de Emilia Pardo Bazán a José Yxart', 409. 
correspondence with him records: 'El [libro] de Stuart Mill me entusiasmó - voy a publicarlo lo más pronto que pueda-. Ya lo encargué'. ${ }^{36}$

It should be remembered that, by the close of 1890, Pardo Bazán had pledged to live by her pen and had established to that end three ambitious projects: an edition of her complete works, the single-authored journal Nuevo Teatro Critico, and the BDLM series. Moreover, each project was intended to reinforce the other. Adverts for her complete works and for the BDLM appeared in the Nuevo Teatro Crítico and vice versa. Her Prologues to the editions of Sor María, Mill, and María de Zayas appeared as stand-alone articles in the journal, partly, one imagines, to make maximum use of precious material, partly as free advertising for the new venture. In short, she was seeking what Cristina Patiño Eirín has referred to as 'autoencumbramiento', an assertive push to the forefront of the nation's cultural life where her brand could be consumed in multiple forms ${ }^{37}$ Nor did her 'temerity' go unnoticed. Rather the opposite was the case, inasmuch as her endeavour proved so successful that she attracted the opprobrium of misogynistic male contemporaries, among them Leopoldo Alas, José María de Pereda, and José Zorrilla; the latter of whom applied to her at this time his waspish epithet, 'la inevitable', while the former subjected her to a vituperative campaign which she would still recall with dismay in 1901: 'pasé cuatro o seis años de mi vida sin que un solo instante dejasen de resonar en mis oídos los ladridos furiosos del can'. ${ }^{38}$

Faced with such a punishing workload - throughout 1892 the Nuevo Teatro Critico alone required 112 pages of copy every month - something had to give and the BDLM appears to have suffered as a consequence. ${ }^{39}$ Pardo Bazán advertised the imminent publication of ten further volumes that never in fact saw print. Some are readily identified from the lists of forthcoming titles advertised on the flyleaves of the BDLM editions. The expanded series was to include translations of Henry Blaze de Bury's Les Maîtresses de Goethe (1873), Alfred des Essart's La Femme sans Dieu (1875), George Eliot's Adam Bede (1859), Mme Émile de Girardin's Contes d'une vieille fille à ses neveux (1833), León Hebreo's Dialoghi di amore di Leone Hebreo medico (1502), Antoine Auguste Léopold Pauthe's Sainte Marcelle: la vie religieuse chez les patriciennes de Rome au quatrième siècle (1880) and Madame de Staël's Dix années d'exil (1818). A final addition to the 'economía doméstica' section was promised, under the title Bebidas, tés y refrigerios, but failed to materialize. Three further titles are less easily identified for reasons that vary in each case. A volume (or volumes?) entitled Las mujeres de la Revolución Francesa: I: Las Realistas. II: Las Republicanas was advertised and there is indeed no shortage of books on the women of the French Revolution, including a number in Pardo Bazán's extant library. Frustratingly, none that I have identified to date divides the women using the designation 'Realistas' and 'Republicanas'. A book entitled Dias felices by Harriet Beecher Stowe was promised and ought, on the face of it,

\footnotetext{
${ }^{36}$ José Luis Varela, 486.

${ }^{37}$ Cristina Patiño Eirín, 'Génesis, historia y transmisión de los textos de Emilia Pardo Bazán', in Simposio "Emilia Pardo Bazán: Estado de la cuestión”, ed. by José Manuel González Herrán, Cristina Patiño Eirín and Ermitas Penas Varela (A Coruña: Real Academia Galega, 2005), 67-134 (p. 81)
}

${ }^{38}$ Letter to Emilio Ferrari, quoted in Acosta, 448. A perusal of the 'Paliques' written by Clarín from 1890 onwards does indeed reveal the relentlessness with which he attacked her works and personality. See, for example, his Obras completas, ed. by Yvan Lissorgues and Jean-François Botrel, 12 vols. (Oviedo: Nobel, 2003-2009), VIII: Artículos (1891-1894) (2005), 69, 72, 90, 93-94, 114, and passim. He appears, however, to have made no reference to the BDLM. Given the ferocity of Alas's attacks, it is perhaps not surprising that Pardo Bazán's library contained an inscribed copy of Pompeyo Gener's El caso Clarín: monomania maliciosa de forma impulsiva. Estudio de psiquiatría (Barcelona: Llorachs; Madrid: Fernando Fé, 1894).

${ }^{39}$ In 1891, each edition of the Nuevo Teatro Crítico contained 96 pages. It expanded in 1892 to 112 pages. The six editions published in 1893 each contained 160 pages. 
prove easy to identify. And yet, Beecher Stowe did not write a book with an equivalent English title. The most likely candidate would appear to be Sunny Memories of Foreign Lands (1854), an account of the author's European travels, but which appeared in two volumes totalling nearly 700 pages. Perhaps Pardo Bazán intended to abridge the text. A final volume referred to only as 'Recuerdos de la vida de Lord Byron, por una dama' has likewise resisted efforts to identify it. Although there is much to learn about the scope and direction of the BDLM from this tantalizing list of non-existent books, limitations of space prevent further discussion of this matter here.

As noted above, the series editor was forced to admit two decades later that her intended audience did not respond in sufficient numbers to persuade her to persist with the considerable labour the BDLM required. Patiño Eirín has observed that the editor set herself ambitious targets where sales were concerned, apparently printing 3,000 copies of each BDLM volume, compared to a standard run of a third or two thirds that number. ${ }^{40}$ One of the few extant documents pertaining to the series in the Real Academia archive are two sheets on which she can be seen working out the costs associated with the project - payments to printers, to the publisher Renacimiento, with whatever remained constituting her earnings. It should be said that things got off to a good start: Sor María's Vida de la Virgen María, which went on sale in February 1892, had sold out by the time Pardo Bazán was advertising La esclavitud femenina in May that same year. ${ }^{41}$ Although the volumes of Sor María and her own Mi romería went into second editions, sales of the others appear to have been sluggish, despite their uniform price of 3 pesetas each. When it became clear that the sales of the BDLM were not meeting expectations, she sought to resurrect the idea that her journal and publishing series could mutually self-support. From November 1892 until the same month of the following year the instalments of the Nuevo Teatro Critico carried adverts offering readers a choice of Volumes II, III, IV or V of the BDLM series for free, as an incentive for subscribing to the journal. ${ }^{42}$ When pressures of time and ill-health forced her to reduce the rate at which she published her periodical from a monthly to a bimonthly instalment in 1893, it was perhaps inevitable that the BDLM would also require scaling back. Thus it was that volume nine, Bebel's La mujer ante el socialismo, remained for twenty years the final word until the cookbooks briefly resumed and completed the series.

\section{Presenting Mill's radical new vision}

To return to the collection's more ambitious beginnings, it is time to address the questions raised around translation, production, and presentation with regard to La esclavitud femenina. As we saw above, the tendency to attribute the translation of Mill to Pardo Bazán herself is no longer tenable. The letter in which she acknowledges Giner's gift of the Mill volume states 'Ya lo encargué, indicating that she has commissioned a translation, something she would confirm a quarter of a century later in an article to mark her friend and mentor's death:

Era Giner resueltamente feminista. Lo que atañía al mejoramiento de la condición de la mujer le interesaba en el más alto grado. Por él conocí yo la famosa obra de Stuart Mill, La esclavitud femenina, que tanto influyó en el movimiento feminista de Inglaterra, y que hice traducir y publiqué en castellano, cuando creía que pudiesen aquí importarle a alguien estos problemas. ${ }^{43}$

\footnotetext{
${ }^{40}$ Cristina Patiño Eirín, in her 'Génesis, historia y transmisión de los textos de Emilia Pardo Bazán', 81.

${ }^{41}$ See advert on flyleaf of Nuevo Teatro Crítico, 17 (1892).

${ }^{42}$ See advert on flyleaf of Nuevo Teatro Crítico, 23 (1892).

${ }^{43}$ Emilia Pardo Bazán, La obra periodística en La Nación de Buenos Aires (1879-1921), ed. by Juliana Sinovas Maté, 2 vols. (A Coruña: Diptación de A Coruña, [n.d.]), II, 990.
} 
Confirmation that she farmed out the translations in the BDLM series is to be found in her review of Boris de Tannenberg's Bibliothéque Espagnole published in La Lectura in 1903:

"Tannenberg supuso que las traducciones de la "Biblioteca de la mujer" eran labor mía. Conservo los recibos de los traductores'. ${ }^{44}$ It is regrettable that those receipts appear not to have survived. Were they to surface, they would provide a window onto the networks of collaboration Pardo Bazán had established among the hack-writers who would have depended on such commissions to earn their living. ${ }^{45}$ A further letter to Giner, sent in either 1891 or 1892, reveals that she had been drawing on contacts in Madrid's publishing world, seeking recommendations from her collaborator on La España Moderna, José Lázaro Galdiano: 'El Sr. Lázaro tuvo muchas recomendaciones para esta clase de trabajo [...] Yo, personalmente, tal vez pueda dar algún trabajo a esa traductora, pero hasta dentro de unos días, que examine los libros que tengo preparados y que tal vez sirvan para el objeto'. ${ }^{46}$

That same letter to Giner starts with an apology for her tardiness in replying that is characteristic of her correspondence in this period. The reason is not far to seek and also explains why she needed to commission the Mill translation rather than take it on herself. Time rather than linguistic competence would have been against her. In fact, she had excellent command of English, as the contents of her library attest. According to data gathered by Mercedes Fernández-Couto Tella, two percent of the holdings in what remains of her library are in English, a figure which appears negligible at first sight but which, given that the complete collection runs to 8,000 volumes, still amounts to approximately 160 books. ${ }^{47}$ More to the point, Pardo Bazán's correspondence is littered with English phrases, indicative of easy familiarity with the language, and she wrote in her 'Apuntes autobiográficos' of having used the free time during her family's self-imposed exile in the wake of the 'Septembrina' to 'repasa[r] mis temas ingleses'. ${ }^{48}$ Motivated by a desire to read Byron and Shakespeare in the original, she clearly stuck to her task, as she was able to show with aplomb in 1883 when engaged in some polite public sparring with the Marqués de Premio-Real on the subject of the Bard's use of language. The Marqués had alleged in a recent publication that among Shakespeare's virtues was 'pulcritud de lenguaje', a suggestion Pardo Bazán quashes with ease by arming herself with the abundant innuendoes in All's Well That Ends Well, Hamlet, Measure for Measure, The Merry Wives of Windsor, Othello, and Romeo and Juliet, all of which she quotes in English. ${ }^{49}$ Her reply demonstrates exceptional familiarity with

\footnotetext{
${ }^{44}$ Review of Bibliothèque Espagnole by Boris de Tannenberg, La Lectura, 3:3 (1903), 102-08 (p. 107).

45 As Leopoldo Alas makes clear, translation was often a disregarded and poorly remunerated occupation in this period. See his 'Las traducciones', in Obras completas, IV (i): Crítica, ed. Laureano Bonet (2003), 83337. For an overview of the translation work Pardo Bazán did in fact undertake, see Ana María Freire López, 'La traducción como obra de arte', in Autores traductores en la España del siglo XIX, ed. by Francisco Lafarga and Luis Pegenaute (Kassel: Reichengerger, 2016), 473-84.

46 'E. Pardo Bazán: Epistolario a Giner de los Ríos’, 476.

${ }^{47}$ Mercedes Fernández-Couto Tella, 'Aproximación ó catálogo da biblioteca de Emilia Pardo Bazán', La Tribuna: Cadernos da Casa Museo Emilia Pardo Bazán, 1 (2003), 251-56.

48 Emilia Pardo Bazán, 'Apuntes autobiográficos', in Obras completas, ed. by Federico Carlos Sáinz de Robles, 3 vols. (Madrid: Aguilar, 1963-1973), III: Cuentos/Critica literaria (selección), ed. by Harry L. Kirby, Jr. (1973), 698-731 (p. 709). Ana María Freire López has shown that the original draft of the 'Apuntes' made reference to the London-based teacher who assisted Pardo Bazán in her efforts to learn English, indicating that she was not solely an autodidact in this instance. See her 'La primera redacción, autógrafa e inédita, de los “Apuntes autobiográficos” de Emilia Pardo Bazán', Cuadernos para Investigación de la Literatura Hispánica, 26 (2001), 305-33.
}

${ }^{49}$ Quoted in Shakespeare en España: Textos 1764-1916, ed. by Ángel-Luis Pujante and Laura Campillo (Granada/Murcia: Universidad de Granada/Universidad de Murcia, 2007), 307-09. 
both a wide range of the canon and the intricacies of Shakespeare's linguistically-complex sexual punning.

One thing not cleared up by Pardo Bazán's letter to Giner is whether the version of The Subjection of Women he sent her was in English at all. The only copy of the text in her personal library was in French, specifically the second edition of L'assujettissement des femmes, trans. by E. Cazalles (Paris: Guillaumin et Cie., 1876). That copy of the text is unmarked and contains no dedication that might clear up its provenance. Given that late-nineteenth-century Madrid almost certainly contained far more translators who could work from French than from English, we must entertain the possibility that the Mill edition was translated via Cazalles's text. Thus, any discrepancy between the English and Spanish versions must be checked against that possible intermediary. As will become clear in the notes below, there is only one instance among the dozens of departures from the original English which can be so attributed.

\section{When La esclavitud femenina appeared in May 1892, La Época and La España Moderna} reproduced verbatim the claim that 'es libro que ha de suscitar muchas polémicas y acaloradas discusiones por lo radical e innovador de las teorías que desarrolla respecto a la situación social y política de la mujer'. ${ }^{50}$ (Whether that is indicative of the time-honoured journalistic wheeze of 'borrowing' copy, or of the phrase appearing in the advertising material Pardo Bazán supplied, may prove impossible to determine.) Anyone familiar with Mill's text scarcely need rehearse a handful of its main arguments to see why it might well prove controversial. Catherine Davies has suggested that Pardo Bazán explicitly augments the resonance of the title by substituting 'esclavitud' for the original - and arguably less loaded - 'subjection'. ${ }^{51}$ And yet, it is a central tenet of Mill's argument that the legal bondage of women in marriage is the last vestige of a system of slavery - 'esclavitud' - that had been eradicated in the Western world:

It is the sole case, now that negro slavery has been abolished, in which a human being in the plenitude of every faculty is delivered up to the tender mercies of another human being, in the hope forsooth that this other will use the power solely for the good of the person subjected to it. Marriage is the only actual bondage known to our law. There remain no legal slaves, except the mistress of every house. ${ }^{52}$

Not only does he liken the current status of women to slavery, he repudiates contemporary assumptions about men's and women's relative capabilities or essential characteristics:

I deny that any one knows, or can know, the nature of the two sexes, as long as they have only been seen in their present relation to one another. [...] What is now called the nature of women is an eminently artificial thing - the result of forced repression in some directions, unnatural stimulation in others. (The Subjection of Women, 493)

Only once the social conditioning of women - imposed by men, for men - were removed could any safe conclusions be assayed as to intrinsic differences between the sexes. He puts forward and contests a number of the arguments alleged in favour of male superiority, among them women's alleged lack of distinction in the arts, their disengagement from politics, even the size of their brains. He concludes that: 'At present, in the more improved countries, the disabilities of women are the only case, save one, in which laws and institutions take persons at their birth, and ordain that they shall never in all their lives be allowed to compete for certain things' (The Subjection of Women, 490). He adds that the sole exception is the line of succession to the throne

50 Anon, 'Nuevos Libros', La Época, $8^{\text {th }}$ June 1892, 4; Anon, 'Libros', La España Moderna, 41 (1892), 20708 .

${ }^{51}$ Catherine Davies, Spanish Women's Writing $1849-1996$ (London: Athlones Press, 1998), 85.

52 John Stuart Mill, On Liberty and Other Essays, ed. by John Gray (Oxford: Oxford University Press, 2008), 469-582 (pp. 557-58). Subsequent references are to this edition. 
which does on occasion allow a woman ultimate sovereignty. A Carlist and a monarchist, Pardo Bazán was sensitive to that exception, as she was to prove in an exchange with the Portuguese novelist José Maria Eça de Queirós. The latter had expressed his consternation that a woman with such progressive ideas in some areas should have shown herself so reactionary in her opposition to Republicanism. Pardo Bazán replied 'Estoy dispuesta a declararme republicana cuando vea que existe una República con presidente hembra. Mientras las Repúblicas sean más sálicas que las Monarquías, éstas tienen toda mi simpatía y adhesión'. ${ }^{53}$

There is always the danger that autobiographical readings of Pardo Bazán's editorial choices in the BDLM will appear to diminish her achievement in bringing the cutting edge of contemporary feminism to Spanish readers. Nothing could be further from my intentions. However, it is the editor herself who initiates the practice by emphasizing in her Prologue the sense that reading Mill's treatise is a way of evoking memories of her liberal and much-grievedfor father: the father moreover whose death in 1890 had bequeathed to her the financial independence underwriting this radical new phase of her career: 'Mi inolvidable padre [...] profesó en estas cuestiones un criterio muy análogo al de Stuart Mill, y al leer las páginas de La esclavitud femenina, a veces me hieren con dolorosa alegría reminiscencias de razonamientos oídos en la primera juventud' (La esclavitud femenina, 48). There is a sense of narrative aptness or poetic justice to that identification which we might acknowledge.

Mill's denunciation of the injustices women face will have resonated strongly with the series editor, though perhaps none more so than his comments on marriage. He rails against a woman's surrendering her legal authority on marriage; against the sexual servitude she must endure in cases where the relationship has become dysfunctional; and against the fact that she has only a single chance to get this most defining of decisions right: in the absence of divorce laws some women will spend a lifetime under the legal authority of men they despise. As he observes, "legal separation, until lately, the courts of justice would only give at an expense which made it inaccessible to any one out of the higher ranks' (The Subjection of Women, 505). It is here that the autobiographical reading of her editorial selection intrudes on territory very much not for public airing. His words cannot but have resonated with Pardo Bazán since she was among the privileged minority who had been able to access just such legal recourse when her own marriage to José Quiroga broke down in 1883. Eva Acosta and researchers at the journal La Tribuna have documented the somewhat tawdry disputes that caused not just marital relations but also those between their respective families to fracture over the course of their unhappy union. ${ }^{54}$ That archival work revealed the root cause to be the deceitful conduct of José Quiroga's father, who reneged on a promise to divide his estate equally between his first- and second-born sons in his will. Upon his death it became clear that the financial contribution to the marriage from the Quiroga family was to be far below what Pardo Bazán's parents believed had been agreed and the sense of slighted honour appears to have festered thereafter. Thus, when José later sought to exercise his marital 'authority' over his wife, and force her withdrawal from public life in the wake of the controversies over Naturalism, she washed her hands of him. Mill had warned in The Subjection of Women that: 'A woman who joins in any movement which her husband disapproves, makes herself a martyr, without even being able to be an apostle, for the husband can legally put a stop to her apostleship' (The Subjection of Women, 556); not so, in Pardo Bazán's case. But hers were particular and privileged circumstances, as the La Tribuna researchers demonstrated.

${ }^{53}$ Quoted in Ana María Freire, 'Emilia Pardo Bazán y el género periodístico de la entrevista', Studi Hispanici, 38 (2013), 197-224 (p. 210).

${ }^{54}$ Acosta, 119-23; Grupo de investigación La Tribuna, 'Aportaciones a la biografía de Emilia Pardo Bazán. La crisis matrimonial (1875-1884)', La Tribuna: Cadernos da Casa Museo Emilia Pardo Bazán, 6 (2008), 71 127. 
Among the hitherto unseen documents they uncovered was the draft of a legally binding agreement she evidently put before her husband in 1884 and in which he would pledge to renounce his claims to her property: what amounted to a legal separation in a country which made no legislative provision for divorce. (It remains unclear whether he ever signed such a document.) Her candid correspondence with González de Linares reveals the regret she experiences when thinking 'que mi sangre corra por las venas de mi hijo, unida a la suya'. ${ }^{55}$ In other words, she knew all too well the visceral revulsion a wife tied to an unworthy husband must endure. By publishing Mill in Spain, Pardo Bazán could be thought of as inviting debate about the wider availability of privileges to which her status had already given her access.

The Subjection of Women goes further than simply denounce the harm caused by the status quo, it argues for the obvious benefits to the individual and society that would derive from women's emancipation: the greater happiness of half of the human race, women's contribution to all fields of knowledge, better political decision-making, up to and including more satisfying marriages. Personal circumstances contributed to Mill's certainty in that regard; his prolonged friendship, collaboration, and eventual marriage with Harriet Taylor having provided an indispensable testing ground for his philosophical inquiries: 'Hardly anything can be of greater value to a man of theory and speculation who employs himself in collecting materials of knowledge by observation [...] than to carry on his speculations in the companionship, and under the criticism, of a really superior woman' (The Subjection of Women, 534). Pardo Bazán dwells in her Prologue on the unusual biographical circumstances that had shaped Mill's adult life, namely his maintaining for twenty years a reciprocal and loving relationship with a woman who had the misfortune already to be married to someone else. Lest her readers should be shocked by the unusual scenario, she quotes from Mill's Autobiography his emphasis on their chaste conduct prior to the demise of Harriet Taylor's husband. Pardo Bazán urges: 'No demos aquí al dulce nombre de amiga el sentido más que profano que tiene en nuestra castiza habla' (La esclavitud femenina, 31). Rather than dwell pruriently on such accidents of fate, she instead explores the richness and mutuality implicit in the meeting of true minds they experienced. To do so, she indulges more abstract considerations about how women are represented in literature, taking Dante's Beatrice and Don Quijote's Dulcinea as her models. What those examples have in common is of course that the women in question are no more than projections of the male gaze:

son formas de una idealidad que busca en la abstracción y el símbolo lo que no quiso encontrar en la realidad y en la vida. Poetizaban aquellos insignes artistas a la mujer, como poetizamos al árbol, a la fuentecilla, a la pradera, al mar, que sabemos que no nos han de entender, porque no tienen entendimiento, ni nos han de corresponder, porque no están organizados para eso, y así es nuestra propia alma la que habla al mar y la que en la voz del mar se responde a sí misma. ( $\mathrm{La}$ esclavitud femenina, 38)

The example offered by Taylor and Mill may be less 'estético' but it is certainly more 'moral y fortalecedor'. To understand, respect, love, and learn from one's partner in marriage looks like a utopian dream but Pardo Bazán uses her Prologue to emphasize that it could be the shape of the world to come.

However, we have already seen from her first selection as series editor that she was anxious to emphasize her credentials as custodian of her readers' morals. Her opening gambit in the BDLM made plain her Christianity and her patriotism. Thus she tackles head-on the potentially thorny subject of Mill's personal life but also offers her readers a rhetorically astute get-out clause for those moments when Mill's argument appears unsettlingly radical: 'Es imposible estar de acuerdo en todo con ningún libro, ni aun con el Evangelio, lo cual no quita

${ }^{55}$ Faus, I, 303. 
que el Evangelio sea la pura verdad, de pies a cabeza; sólo que nuestro entendimiento no abarca entera esa verdad' (La esclavitud femenina, 50). While offering reassurance to those left queasy by the sight of Mill's brave new world, Pardo Bazán is also drawing an implicit equivalence between his text and gospel truth: yet more evidence of how she thought it best to persuade and cajole her intended audience. She even rehearses what she believes the best reaction to any such queasiness should be: 'Hay varios puntos en que yo disiento de Stuart Mill; ¿qué importa? en el conjunto me parece que palpita una gran rectificación de errores, y se desprenden fecundísimas enseñanzas' (La esclavitud femenina, 50). It is towards the end of her Prologue that the tone shifts, as if rallying her readers: his arguments are 'de hierro batido y acero bien templado' (La esclavitud femenina, 52), linking them semantically to the iconic symbols of nineteenth-century progress railway lines, the wrought-iron exhibition halls at the World's Fairs, or the newly-opened Tour Eiffel. Her final paragraphs reflect on recent progress towards female suffrage in Britain:

diré que su campaña no ha sido estéril y ya puede contársele entre los mayores bienhechores de la mujer en el terreno positivo. Cuando en 1867 presentó a la Cámara de los Comunes el proyecto de ley pidiendo para la mujer el derecho de sufragio, la minoría que votó con él fue lucida e imponente, y general la sorpresa de sus adversarios viendo que no podían tildarle de extravagancia. (La esclavitud femenina, 52).

The implication is: 'Anything they can do, we can do better'.

\section{The Devil In The Detail: Shifts OfEmphasis And Nuance In La esclavitud femenina}

When it comes to the text itself, the most striking change is the division of Mill's four substantial chapters into thirty-six smaller units in the Spanish edition. Those shorter chapters are also given headers to summarize the on-going argument and more frequent paragraph breaks than the original English. ${ }^{56}$ The motivation for such changes is most obviously to render a complex discussion more manageable, particularly for those less familiar with the conventions of philosophical exposition. That tendency can further be noted in the efforts to condense Mill's occasionally tortuous sentence construction. For example, Mill denounces the emotionally impoverished relationships that ensue when a man marries a woman he neither knows nor respects, claiming that each partner: 'has as little admission into the internal life of the other as if they were common acquaintance'. The Spanish version puts this more succinctly: 'son dos conocidos, dos extraños' (The Subjection of Women, 496; La esclavitud femenina, 125). ${ }^{57}$ In setting out his exposition of the problems that arise when fighting against society's most cherished beliefs, Mill comments: 'I do not mention these difficulties to complain of them; first, because it would be useless; they are inseparable from having to contend through people's understandings against the hostility of their feelings and practical tendencies'. The Spanish version again supplies greater immediate clarity: 'Si hago presentes estas dificultades, no es por quejarme de ellas, que de nada serviría; ya sabemos que con ellas se ha de luchar a brazo partido y cuerpo a cuerpo' (The Subjection of Women, 473; La esclavitud femenina, 64)..$^{58}$

The general impression produced when the translations are compared line by line is favourable. The Spanish text follows the English faithfully and accurately. Culturally specific and

${ }^{56}$ The Cazelles French edition retains Mill's original chapter divisions and does not supply summaries.

${ }^{57}$ Cazelles reads: 'Il y a souvent entre une femme et son mari une unité complète de sentiments et une communauté de vues quant aux choses extérieures, et pourtant l'un ne pénètre pas plus profondément dans les vues de l'autre que s'ils n'étaient que de simples connaissances' (L'Assujettissement des femmes, trad. Cazelles, 19-20).

${ }^{58}$ Cazelles reads: 'Si je rappelle ces difficultés, ce n'est pas pour m'en plaindre, cela ne servirait de rien ; elles se dressent sur le chemin de tous ceux qui attaquent des sentiments et des habitudes par un appel à la raison' (L'Assujettissement des femmes, trad. Cazelles, 5). 
therefore potentially confusing references have been ironed out by someone sensitive to the needs of a Spanish readership. Thus Mill's designation of 'Mrs Grundy' to stand in for the English everywoman is translated simply as 'la mujer' (The Subjection of Women, 569, 571; La esclavitud femenina, 318, 325). ${ }^{59}$ A passage in which Mill refers to 'Sergeant Talfourd's Act' (which had reformed legislation around a separated woman's access to her children in the late 1830s) becomes simply 'una ley' (The Subjection of Women, 505; La esclavitud femenina, 146). ${ }^{60}$ Alongside such judicious suppressions, the translation also makes naturalizing additions to help its target audience. When argument turns to 'the suffrage, both parliamentary and municipal', the translation deftly expands the legislative bodies referred to, in deference to Spain's distinct electoral system: 'Quiero hablar del derecho electoral, así en el Parlamento como en los Cuerpos provinciales y municipales' (The Subjection of Women, 526; La esclavitud femenina, 202) ${ }^{61}$ Moreover, the Spanish version draws on the language's rich heritage of rhymed 'refranes' to explicate Mill's distaste for the unequal settlement of property in marriage, that sees men retaining exclusive control of all goods, no matter their origin: 'I have no relish for a community of good resting on the doctrine, that what is mine is yours but what is yours is not mine'. The Spanish uses an unattributed quotation from the poem 'El tambor' by Juan Martínez Villergas (1816-1894) to capture this same idea: 'No tendremos desafío, / Por eso, niña de Dios. / Bien está: lo mío, mío, / Y lo tuyo... de los dos' (The Subjection of Women, 521; La esclavitud femenina, 190). ${ }^{62}$

And yet, comparison of the translations also reveals unobtrusive but telling modifications; in particular, passages where Mill's argument has been made subtly more emphatic. Taken together those passages suggest the intervention of the series editor at some stage in the book's production. Before providing the examples to illustrate that interpretation, it is worth noting another of the surviving documents pertaining to the BDLM in the Real Academia Galega. That document is the galley-proof manuscript of the translation of Gonzalve de Nervo's Historia de Isabel la Católica. What is notable about the manuscript is that it has been heavily annotated in a hand that looks very much like that of Pardo Bazán with changes to the punctuation, syntax, and word choice. It is effectively a late-stage intervention to polish the prosody so as to ensure its quality. If, as we have noted, the editor was in no position to produce the translations herself, she could at least put her stamp on them prior to their going to press. The manuscript of Historia de Isabel la Católica would support such a view.

Of all the amendments to Mill's text, there is one in particular that bears Pardo Bazán's hallmark. It occurs in a passage addressing the need for greater legislative protection for women, on the basis that assumed male chivalry cannot guarantee their long-term safety: 'But the real dependence of morality must always be upon its penal sanctions - its power to deter from evil. The security of society cannot rest on merely rendering honour to right, a motive so comparatively weak in all but a few'. More than a hint of Cervantine homage creeps into the Spanish version of the second sentence just quoted: 'La seguridad social no podrá descansar en

\footnotetext{
${ }^{59}$ In the first of these examples, Cazelles reads: 'Quiconque a une femme et des enfants a donné des otages à l'opinion du monde' (L'Assujettissement des femmes, trad. Cazelles, 70). In the second, it reads: 'en réduisant l'esprit des femmes à une nullité telle qu'elles n'ont d'autre opinion que celle de leur monde ou celle que leur mari leur souffle' (L'Assujettissement des femmes, trad. Cazelles, 73).

${ }^{60}$ The Spanish appears to follow Cazelles here: 'jusqu'à l'époque récente où ce pouvoir fut restreint par une loi' (L'Assujettissement des femmes, trad. Cazelles, 26).

${ }^{61}$ Cazelles reads: 'Je veux parler du suffrage pour les élections tant du parlement que des corps municipaux' (L'Assujettissement des femmes, trad. Cazelles, 41).

${ }^{62}$ Cazelles reads: 'Mais je n'ai aucun goût pour la doctrine en vertu de laquelle ce qui est à moi est à toi, sans que ce qui est à toi soit à moi' (L'Assujettissement des femmes, trad. Cazelles, 37).
} 
tan inseguros cimientos como la honra que gana un caballero enderezando tuertos y descabezando vestiglos' (The Subjection of Women, 565; La esclavitud femenina, 308) ${ }^{63}$ While the phrasing would have been familiar to any educated Spaniard, it is the kind of rhetorical flourish that the translator avoids elsewhere in La esclavitud femenina. Another reason for suggesting it to be a late addition by the editor is that it is one of Pardo Bazán's favourite phrases. She used that same passage from Don Quijote in the mission statement for the Nuevo Teatro Critico the year before. ${ }^{64}$ Back in her 1883 novel, La Tribuna, she had described the heroine as 'herida y maltrecha de su primera salida en busca de aventuras'. ${ }^{65}$

If we examine other amendments to the English text, they too are suggestive of an interventionist strategy adopted by one of the text's creators. Two in particular indicate that the editor believes Mill to be selling both women's past achievements and future possibilities short. His list of roles an Englishman cannot currently imagine a woman fulfilling: 'soldiers or members of Parliament' becomes 'soldados, o miembros del parlamento, o ministros', emphasizing that women's ambitions need not be contained by insidious assumptions (The Subjection of Women, 484; La esclavitud femenina, 93).${ }^{66}$ Mill goes on to observe that in feudal times 'war and politics were not thought unnatural to women, because not unusual'. The Spanish becomes: 'no se encontraba antinatural que las mujeres hiciesen la guerra y dirigiesen la política, porque lo hacían muchas, no sin acierto y brío' (The Subjection of Women, 484; La esclavitud femenina, 93). ${ }^{67}$ Another modification to Mill's portrait of the ideal marriage implicitly flatters the readership for their sensitivity: 'To those who cannot conceive it, it would appear the dream of an enthusiast'. This becomes: 'Los espíritus capaces de suponerla no necesitan mis pinceles, y los miopes verían en el lienzo la utopía de un entusiasta' (The Subjection of Women, 575; La esclavitud femenina, 333). ${ }^{68}$ By dividing the readership into an 'us' who can share that vision and a 'them' who cannot, the text seeks to forge a community of the like-minded. A similar spirit appears to inform the addition to the final lines of chapter 27 (which corresponds with the end of chapter 3 of the original). Mill's text ends with the words: 'Women cannot be expected to devote themselves to the emancipation of women, until men in considerable number are prepared to join with them in the undertaking'. Whereas the Spanish reads more emphatically:

No es dable esperar que las mujeres se consagren a la emancipación de su sexo mientras los varones no estén preparados para secundarlas o ponerse a su cabeza. El día llegará; pero hasta que llegue, ;compadezcamos a la mujer generosa capaz de iniciar la redención de sus compañeras de cadena! (The Subjection of Women, 556; La esclavitud femenina, 283-84) ${ }^{69}$

That call to solidarity, which has no equivalent in the original English, could also be read as an attempt to establish links of sympathy across the fragmented intellectual community of Spanish

${ }^{63}$ Cazelles reads: 'La sécurité de la société repose mal sur une aussi faible sanction que l'honneur qui revient aux bonnes actions'. (L'Assujettissement des femmes, trad. Cazelles, 67).

64 'Presentación’, Nuevo Teatro Crítico, 1 (1891), 5-20 (p. 19).

${ }^{65}$ Emilia Pardo Bazán, La Tribuna, in Obras completas, ed. Sáinz de Robles, II (1964), Novelas y cuentos, 101 96 (p. 181).

${ }^{66}$ Cazelles reads: 'mais ils trouveraient contre nature que des femmes fussent soldats ou membres du parlement' (L'Assujettissement des femmes, trad. Cazelles, 11).

${ }^{67}$ Cazelles reads: 'on ne trouvait pas contre nature que les femmes fissent la guerre et dirigeassent la politique, parce que ce n'était pas rare' (L'Assujettissement des femmes, trad. Cazelles, 11).

${ }^{68}$ It is possible that this addition could be attributed to the French translation. Cazelles reads: 'Les esprits capables de se le représenter n'ont pas besoin de mes couleurs, les autres n'y verraient que le rêve d'un enthousiaste' (L'Assujettissement des femmes, trad. Cazelles, 74).

${ }^{69}$ The Cazelles edition does not contain this additional passage. 
women. It is a way of reminding those progressive and frustrated individuals, who might feel that they are the only members of their social circle to cherish such subversive ideals, that, however lonely their voices may appear, they are not alone. The Spanish text speaks directly to those women again when it modifies Mill's characterization of the human yearning for liberty common to both sexes: 'Let his [feelings] rest assured that whatever he feels on this point, women feel in a fully equal degree'; 'Vivamos seguros de que cuanto sienten los hombres en punto a libertad, lo sienten las mujeres en el mismo grado, aunque callan; y lo sienten más de adentro, cuanto más dignas e ilustradas son' (The Subjection of Women, 577; La esclavitud femenina, 338). ${ }^{70}$ Not only does the Spanish version validate women's frustrations, it dignifies them as the righteous response to injustice. And the intensity with which they feel them even becomes a barometer of their fortitude and intelligence. While seeking to define and value its community of disenfranchised women, the translation also makes full use of the restrained criticisms Mill directs at those opposed to female emancipation. He remarks on the 'lovers of fun' who mock the idea by producing caricatures of a parliament filled with teenage girls or newly-married women in their twenties. His next sentences read: 'They forget that males are not usually selected at this early age for a seat in Parliament, or for responsible political functions. Common sense would tell them...'. The translation exploits the opportunity to hammer home just how worthy of scorn such opponents are: 'Olvidan estos payasos que el hombre tampoco es llamado a esa edad a sentarse en el parlamento ni a desempeñar funciones responsables. El mero buen sentido debiera dictarles...' (The Subjection of Women, 580; La esclavitud femenina, 346). ${ }^{71}$ The addition of 'payasos' and the augmentative 'mero' speak for themselves. We can observe the same tendency to insert clarifications that emphasize just how stark the situation confronting women is in the following modification of Mill's English: 'it were greatly to be lamented that the chivalrous standard should have passed away, for it is the only one at all capable of mitigating the demoralizing influences of that position'; 'debemos lamenter que el tipo caballeresco haya desaparecido, porque sólo él podría moderar la influencia desmoralizadora de la esclavitud de media humanidad' (The Subjection of Women, 564; La esclavitud femenina, 306). ${ }^{72}$

Underlying a final group of amendments would appear to be a desire to avoid causing offence to a potentially conservative Spanish readership. We saw above that Pardo Bazán forewarned her readers that they were likely to disagree with passages in La esclavitud femenina. Perhaps that is why she felt able to leave intact two of Mill's more forthright denunciations of the Catholic Church: its malign influence on the people of Ireland or its usurpation of a husband's marital authority throughout the territory where it holds sway (The Subjection of Women, $539,571)$. And yet, Mill's sceptical remarks on the sincerity of most people's faith is attenuated so as to elide its combative tone: 'We daily see how much their gratitude to Heaven appears to be stimulated by the contemplation of fellow creatures to whom God has not been so merciful as he has to themselves' becomes instead 'Con frecuencia vemos que el hombre adora a Dios más profundamente cuando se cree castigado, anonadado por él' (The Subjection of Women, 507; La esclavitud femenina, 152-53). ${ }^{73}$ What had, in its original form, been a denunciation of hypocrisy now

\footnotetext{
70 The Cazelles edition does not contain this additional passage.

${ }^{71}$ Cazelles reads: 'Ils oublient que les hommes ne sont pas appelés à cet âge à siéger au parlement, ni à remplir des fonctions responsables. Le simple bon sens devrait leur apprendre...' (L'Assujettissement des femmes, trad. Cazelles, 77).

${ }^{72}$ Cazelles reads: 'si les femmes devaient rester dans leur position subordonnée, il faudrait regretter que le type chevaleresque ait péri, car seul il pourrait en modérer l'influence démoralisatrice' (L'Assujettissement des femmes, trad. Cazelles, 67).

${ }^{73}$ Cazelles reads: 'Nous avons fréquemment occasion de voir que ce qui développe le plus la reconnaissance des hommes pour le Ciel, c'est la vue de ceux de leurs semblables pour qui Dieu ne s'est pas montré aussi miséricordieux que pour eux-mêmes' (L'Assujettissement des femmes, trad. Cazelles, 28).
} 
reads as a conventional piety. When Mill wishes to evoke women's fortitude in the face of suffering, he refers to their courage 'at the stake', most readily calling to his readers' minds images of witch trials or Catholic 'autos-da-fé'. It is perhaps not surprising that the instrument of death evoked in the Spanish version should instead be 'el cadalso' (The Subjection of Women, 537; La esclavitud femenina, 231). ${ }^{74}$

\section{Conclusion}

As this article has shown, Pardo Bazán worked with exceptional diligence and sensitivity to seek a Spanish readership for The Subjection of Women. Through the BDLM she sought to create a community of readers prepared to critique the barriers placed in the way of their deliverance, as well as the ideological underpinnings of the society they inhabited. She was careful to think through how the books she published under its imprint might by turns reassure and challenge those readers. Her presentation of Mill's tract informs them of the pivotal role Harriet Taylor had played in its genesis, thus setting up a further example of the heights of intellectual achievement to which an emancipated woman could aspire.

The additions to La esclavitud femenina, evident when the English and Spanish versions are compared in detail, indicate a desire to facilitate the text's comprehension in its new linguistic context, to forge a community of the likeminded, and to make Mill's unanswerable case more emphatic still. By contrast, the amendments and slight suppressions from the English to the Spanish versions endeavour to attenuate those aspects of the original most in danger of offending the sensitivities of a Catholic readership. While the evidence presented here makes plain that La esclavitud femenina was not Pardo Bazán's own work, those additions and suppressions bear her distinctive hallmark and offer suggestive indications of her intervention late in the book's drafting. Perhaps we might call it hers after all.

${ }^{74}$ Cazelles reads: 'non seulement sur le bûcher' (L'Assujettissement des femmes, trad. Cazelles, 48). 